Dorothea Alewell, Tobias Moll*

\title{
An Exploratory Study of Spirituality in German Enterprises ${ }^{* *}$
}

\begin{abstract}
Spirituality at work is increasingly attracting attention in management research, especially in the Anglo-Saxon and Asian contexts. However, for the German context, we know little about spirituality at work from scientific research, and findings and results from other sources are broadly scattered. Using a mixed-methods approach, we collect first findings on employer's perception of spirituality at work and specific HRM practices in German workplaces. We analyse daily newspapers and related best-practice publications and conduct a small-scale qualitative employer survey in Northern Germany. To structure the results, we propose three main impact perspectives on spirituality in the workplace (workforce diversity, employee needs, and employer capabilities) as well as different employer stances in dealing with these three perspectives, from faith-avoiding to faith-based (Miller \& Ewest, 2015). In all three perspectives and stances, companies already implement different HR activities under different expectations and perceptions. Some German organisations already address the needs perspective by room-related tools, working time-related tools, foodrelated offers, and instruments that facilitate coordination and cooperation in multi-religious settings. Employer stances differ concerning religious and non-religious spirituality. While employers view nonreligious spirituality in the company as generally positive (faith-friendly), they are often sceptical of religious spirituality at work (faith-avoiding or faith-safe).
\end{abstract}

Keywords: Spirituality at work, employer stances, HR activities, Germany

(JEL: M500, M540, M590, Z1)

\section{Introduction}

For some years, researchers - often from Anglo-Saxon countries - have been intensely discussing topics of spirituality, faith, and religion at work (Ashmos \& Duchon, 2000; Case \& Gosling, 2010; Krahnke et al., 2003; Krishnakumar \& Neck, 2002; Miller \& Ewest, 2015; Loo, 2017; Mensah et al., 2019; Yang et al.,

* Prof. Dorothea Alewell (corresponding author): University of Hamburg, Department of Business Administration, Chair for Human Resource Management, Moorweidenstraße 18, 20148 Hamburg, Germany. Email: Dorothea.Alewell@uni-hamburg.de.

Tobias Moll: University of Hamburg, Department of Business Administration, Chair for Human Resource Management, Moorweidenstraße 18, 20148 Hamburg, Germany. Email: Tobias.Moll@uni-hamburg.de.

** Date submitted: April 4, 2019.

Date accepted after double-blind review: November 25, 2020. 
2019; Heliot et al., 2020; Alewell \& Rastetter, 2020). There is a broad discussion on

- the what of faith, religion and spirituality at work, on terms and concepts;

- the how, and tools and policies applied; and on

- the why, the effects of spirituality, religiosity, or faith at work on important HRM outcomes - as, for example, performance and job satisfaction, on subjective well-being and subjective perceptions of holistic work-life balance.

There is a broad and overwhelming stance in the international literature that workplace spirituality is an important resource for firms and employees: an individual capability improving performance, an element fostering diversity and a necessary answer to employees' transcendence needs, boosting motivation, well-being and the employers' recruiting potential (Ahmed et al., 2019; Ashmos \& Duchon, 2000; Benefiel et al., 2014; Duchon \& Plowman, 2005; Fry \& Slocum, 2008; Garg, 2017; Giacalone, 2004; Gupta et al., 2014; Houghton et al., 2016; Karakas, 2010; Pandey \& Singh, 2019). On the other hand, there is a critical discussion about the potentially abusive exploitation of spiritual resources of employees (Bell \& Taylor, 2003; Case \& Gosling, 2010; Dickson et. al., 2008; Lips-Wiersma et al., 2009; Neal, 2003; Tourish \& Tourish, 2010). Therefore, spirituality at work, doubtless, is an important field of HRM research - for its positive and negative potential for employees and organisations. Alewell and Moll $(2018,2019)$ show how this discourse on spirituality at work has developed consequentially out of older strands of HRM discussions, for example, on work-life-balance, utilisation of worker capabilities, transformational leadership and more holistic work conceptions. Thus, the significance of spirituality for HRM is firmly established in the research literature (even though it is no mainstream topic).

However, there is only little empirical knowledge about stances of employers and the tools, instruments and practices applied in this field (but see Miller \& Ewest, 2013, 2015; Alewell \& Moll, 2021; Loo, 2017). This knowledge cannot be generalised from country to country or continent to continent as spirituality is a culturesensitive concept. We need studies for specific countries and regions because these may differ greatly concerning aspects of spirituality for several reasons (Hollenbach, 1993; Marty, 1993; Silk, 2005; Bäckstrom, 2014): Religion is an important element of spirituality and spiritual traditions in a country. The occurrence and distribution of specific religions or religious confessions and related forms of spirituality differ greatly between continents, countries, and regions. Even countries with a shared religious background may exhibit many differences concerning the social handling of religion (Marty, 1993; Habermas, 2006; Bäckström, 2014). For instance, there are strong differences concerning religion as a private or a public matter between Germany and France with their common Christian background (Ziegler, 2013; Marty, 1993; Bäckstrom, 2014), and, there are large differences between Germany and the U.S.A. concerning the percentage of people who state that 
religion is very important for them (Pew Research Center, 2002, 2015). Many of the existing studies on faith or spirituality at work in Western countries stem from Anglo-Saxon countries. However, the U.S.A. has a clear standalone position concerning religion's role: While in all other Western countries, religion's role in society strongly decreases with economic well-being, this is not the case for the U.S.A. (Pew Research Center, 2002, 2015). Thus, the effects and handling of religion and spirituality - and with that, effects of spirituality at work as well as firms' activities and individual and organisational stances - may differ greatly between different countries, regions, and cultural spheres. Thus, we need culture-specific or country-specific analyses on spirituality at work (see also Moll (2020) with a development of scales for Germany).

Our focus is on Germany. To our best knowledge, there have been no large-scale studies on spirituality in German workplaces (however, see Gebert et al. (2014) on religious diversity management), though there is some scattered small-scale and anecdotic information. Nevertheless, whether spirituality at work is a topic at all in Germany's business world, or whether it is a field that researchers are interested in but which businesspeople perceive and interpret as remote and very far from business and which is not part of any HRM decisions is not yet clear.

We thus seek to shed light on what we do and do not empirically know about spirituality at work in Germany. We collect the scattered evidence and structure the findings along with tools and instruments, aims and impact dimensions (perspectives of workplace spirituality) and employers' stances on workplace spirituality. Finally, we point out research deficits and research questions to guide further studies on spirituality at work in Germany.

The remainder of this paper is structured as follows: After defining and explaining our interpretation of key terms and concepts, we provide a brief and structured overview of the discussion of spirituality at work, developing a classification system to organise the anecdotal empirical evidence and to guide us on what to look for concerning spirituality at work (Section 2). In Section 3, we present and organise the sparse empirical knowledge on faith and spirituality at work in Germany within this frame. In Section 4, we conclude with a summary and avenues for future research.

\section{Spirituality in the Workplace: What to Look for}

\section{Definitions of Terms}

The word spirituality is rooted in the Latin word spirit. It denotes a person's inner life, the life of the spirit and a person's soul. It is shaped by the search for meaning and the human need for and experiences of transcendence and connectedness with a higher power outside the self and with other persons (Mitroff \& Denton, 1999, p. 83). If a specific religion shapes spirituality, we call this spirituality religiosity. Reli- 
gion is a multidimensional construct, denoting a collective set of beliefs, practices, rituals, and ceremonies relating to the sacred and transcendent, and is often based on long traditions and has strong institutional underpinnings (Kaufmann, 2001, p. 282).

Under this definition, religiosity is always spirituality, but there is spirituality that is independent of any religion. Similarly, Krishnakumar and Neck (2002) argued that spirituality implies an inner search for meaning or fulfilment, which can (but does not have to) be independent of religion and may relate to religious or non-religious persons. Other authors differentiate sharply between religiosity and spirituality and demarcate the two constructs (Duffy, 2006; Graber, 2001; Joelle \& Coelho, 2019; Mitroff \& Denton, 1999; Petchsawang \& Duchon, 2009; Zinnbauer \& Pargament, 2005). However, empirically, it is often not possible to separate religiosity and spirituality clearly, especially for non-monotheistic religions or for religions with many submovements or small subgroups and few overarching collective norms, rituals and practices. Even for monotheistic religions, we cannot clearly demarcate spirituality and religiosity. For example, if individuals partially depart in their individual spirituality from the official and collective doctrines of their religion - is it then religiosity (religious spirituality) or spirituality (nonreligious spirituality)? Moreover, spiritual traditions, for example, meditation and religious practices (e.g. prayer) have a strong overlap - there is, for example, the Christian tradition of the "meditation of the heart", a special form of prayer using meditation. Thus, spirituality and religiosity cannot be separated clearly, if we do not concentrate on 'pure' forms of religiosity and nonreligious spirituality only and neglect all 'mixed' forms. The latter strategy does not seem applicable to empirical research. In doing so, we would lose most spiritual persons out of sight. We, therefore, do not follow this line of definition but use spirituality as a generic or superordinate term, which includes strictly religious and strictly non-religious forms of spirituality, and all the non-pure mixed forms between these. We thus use the word spirituality as Miller and Ewest (2015) use faith - but do not follow Miller and Ewest (2015) in their denomination of generic spirituality as faith because the German translation of faith (Glaube) has an explicitly religious connotation and could be misleading in our research context for Germany. However, we stress that individual, public and scientific perceptions of religious spirituality may differ strongly from perceptions of non-religious spirituality. We will return to this aspect in Section 4.

Nonetheless, in our context, we focus not on individual spirituality but spirituality at work, and its relation to HRM. Ashmon and Duchon (2000, p. 137) defined spirituality at work as the (employers and organisational decision-makers') recognition that employees have an inner life that nourishes and is nourished by meaningful work and that takes place in the context of community. Krahnke et al. (2003, p. 91) defined workplace spirituality as a framework of organisational values evidenced in a culture that promotes employees' experiences of transcendence through the work process and that facilitates their sense of being connected to others in a way 
that provides feelings of completeness and joy. Both definitions focus on spirituality at work as a cognitive framework or recognition on the organisational level and the employers' side and with positive content - as a framework that facilitates, enables or fosters individual spirituality at work.

In this paper, we follow this idea and look at a framework of employers' stances or values on spirituality at work from a perceptional level. Beside the attitudes and values, this framework includes the decisions on instruments, tools and regulations flowing from these stances and values, which find an expression in the application or non-application of such tools, practices and instruments. We ask for how decision-makers in firms perceive (individual) spirituality, which stances or attitudes employers take on and which expectations they develop - and on the effects in the application of tools and instruments.

\section{Employers' Stances regarding Spirituality at Work}

Organisations and employers may develop very different stances concerning spirituality at work. Miller and Ewest (2015) developed a framework for analysing faith at work in which they categorise different organisational stances on (religious and non-religious) spirituality (which they denote as faith): faith-avoiding, faith-based, faith-safe, and faith-friendly organisations (Miller \& Ewest, 2015, pp. 307):

- A faith-avoiding (in our terms: spirituality-avoiding) organisation does not accommodate religious requests by employees or tries to suppress such requests. It associates religious expression with fundamentalism, extremism or harassment, and believes that secular neutrality ensures an equal footing for all religious traditions.

- Faith-safe (in our terms: spirituality-safe) organisations meet the spiritual requests of their employees and other stakeholders as necessitated by the law, give priority to avoid undue burden on or the disruption of business, and design policies to avoid litigation. Diversity frames focus on tolerance and understanding of those with varying religious traditions but still encourage greater identity with the predominant faith tradition.

- Faith-based (in our terms: spirituality-based) organisations accommodate requests by employees and proactively embrace religion in formal policies but often privilege one religious tradition above others, for instance, the company founder's religion. Diversity frames focus on tolerance of those outside the privileged religious tradition.

- Faith-friendly (in our terms: spirituality-friendly) organisations value employees' faith, respect their accommodation requests and actively seek out employees' religious and spiritual needs. They support every member of the organisation, regardless of religious orientation, including atheists. Diversity frames focus on un- 
derstanding and agreements between those with varying religious and non-religious traditions.

\section{Employers' Perspectives on and Expected Effects of Spirituality at Work}

Organisations may view and develop their organisational framework under at least three perspectives: They may focus on spiritual diversity, on the expression of spirituality at work as an employee need and/or on spirituality as an individual capability. Under these perspectives, organisations may expect differing impacts or effects of spirituality in the workplace. For instance, the diversity perspective may foster attributions of spiritual heterogeneity, foreignness, conflict, (non-)discrimination, valuable variety and team creativity. The capability perspective relates to individual creativity and resilience to stress. The needs perspective relates to the satisfaction or deprivation of human needs, and thus to organisational commitment, motivation and retention of employees. We expect that differing perspectives on spirituality correlate with different stances of how organisations accommodate spirituality and with the resulting use of differing instruments:

\section{The Diversity Perspective}

An argument for considering religious spirituality in HRM follows from German law, especially the Constitution (Grundgesetz) and the General Law on Equal Treatment (Allgemeines Gleichstellungsgesetz/AGG) (Alewell \& Rastetter, 2020). Both refer to religion as an important dimension of equality and human rights. They stipulate equal treatment of persons of different religious confessions and recognise people's right to live differing religious traditions and to freely express their religious identity. The co-determination law stipulates that the works council and the employer must foster equal treatment of persons of different religious confession, reinforcing the Constitution and the AGG. To comply with these employee rights, firms will have to pay attention to religion and religiosity.

However, the law's impact can be ambivalent (Alewell \& Rastetter, 2020): While explicit regard for topics of religiosity and spirituality may further compliance with these laws, it may also increase the focus on religion, religiosity and spirituality as a personal characteristic - and may result in increasing discrimination, non-inclusion or other negative forms of reference on these dimensions. Thus, individuals may be reluctant to provide information on this non-observable and private characteristic. Also, firms' perceptions of the likelihood of detection after non-compliance with the law, their perceptions of how likely sanctions after noncompliance with the law are, and the perceived cost of noncompliance will influence their compliance activities.

In this perspective, organisations may interpret different forms of individual spirituality and religious confessions of their employees as a dimension of diversity. A positive valuation of these differences may find expression in the design of broad oppor- 
tunities to express differing forms of spirituality. A more negative emphasis on the dangers of discrimination and conflict will result in a focus on laws on equality and religious freedom granting individuals rights to express their religious identity and anti-discrimination provisions.

We assume that a spirituality-avoiding or spirituality-safe approach fits this focus well. Organisations that take this perspective may implement practices and instruments with the aim to protect individual spiritual freedom, to avoid conflict and dissent concerning spirituality, and to assure non-discrimination, for instance, via the use of intercultural calendars, assuring religion-neutral selection and development procedures, installing intercultural agents, and improving managers' spiritual awareness.

\section{The Needs Perspective}

Duchon and Plowman (2005) stated that employees have spiritual needs "just as they have physical, emotional, and cognitive needs." (Duchon \& Plowman, 2005, p. 811). Such needs for transcendence and religiosity are part of being human, and because labour capacity is tied to persons, their spiritual and religious needs are relevant at work - just as other human needs are. Positive psychology has produced many studies on the positive link between religious or non-religious spirituality and individual well-being (Kim-Prieto, 2014; Garg, 2017; Mensah et al., 2019). Case and Gosling (2010) argued that spiritual leaders can create meaning or calling which support the development of organisational and social cultures. In turn, this may lead to the emergence of an authentic sense of membership for leaders and followers (Case \& Gosling, 2010, p. 265) resulting in beneficial effects for both followers and leaders (Yang et al., 2019). Konz and Ryan (1999, p. 202) made an even stronger point: "individuals are expecting organisations designed to promote their search for meaning or transcendence."

In this perspective, spirituality is an important feature in employees' lives and is present at work, too. Explicitly regarding spiritual and religious needs may improve the work atmosphere and may meet employees' needs for meaning, belonging and connectedness with a higher power. Thus, in this needs perspective, organisations must address spirituality - which may even become an important factor in recruiting and retaining employees.

We expect that firms that focus on needs fulfilment will often adopt a spiritualityfriendly or spirituality-safe approach. They may implement practices that allow employees to satisfy their spiritual needs at work: instruments that allocate time and flexibility for expressing spirituality, for instance, prayer breaks, religion-specific working hour regimes (e.g. during Ramadan), and instruments that make room for the expression of spirituality, for instance, rooms of silence, prayer rooms or yoga gyms. 


\section{The Capabilities Perspective}

Organisations may interpret spirituality as a basic human capability that they can use as a resource to increase performance. However, there is a critical discussion about the relationship between spirituality and performance. Giacalone (2004, p. 418) argued that (religious and non-religious) spirituality is necessary in the work context to preserve humanity and employees' performance potential in an increasingly competitive work environment. Fry and Slocum (2008), as well as Duchon and Plowmann (2005), argued for a win-win situation between workers and firms regarding workplace spirituality. Other researchers fear spiritual exploitation of workers, especially with strong power differences between workers and supervisors (Lips-Wiersma et al., 2009, p. 294; Tourish \& Tourish, 2010, p. 217).

In another strand of argumentation, authors interpret the development of spirituality at work as part of a large social movement that is neither driven by managers nor controllable by a single organisation. They describe spirituality at work as a rollback away from the performance-oriented control carried out by employers and away from the hegemony of an intendedly purely rational world (Casey, 2002, p. 165; Mirvis, 1997, pp. 203-204; Ashmos \& Duchon, 2000, p. 135; Tourish \& Pinnington, 2002, p. 166). This implies that the (mis)use of spirituality to keep people calm during economic and societal crises may break free as an independent movement. However, Case and Gosling (2010) countered with Marx's argument that religious beliefs may be the opium of the people and that spirituality may be an instrument to make people endure crises and bad circumstances. They point out the analgesic qualities of spirituality as well as the ideological alignment provided by its doctrines and practices (Case \& Gosling, 2010, p. 275).

We expect that the capability perspective fits well with a spirituality-based or spirituality-friendly approach. Under this perspective, employers may implement, facilitate or even actively support spiritual activities such as prayer circles, meditation groups or yoga breaks within working hours. Managers may lead employees considering and allowing for spirituality, foster their search for meaning in work, and facilitate the building of community and connectedness with other people, strengthening an individual's perception of their calling and mission in life.

All the stances and perspectives may exist empirically in organisations - in a pure form or in combinations. Taking stock of what we know empirically, we can look for these stances (as basic attitudes or stances of employers) and the dominant content perspectives on spirituality at work.

Interestingly, the differing content perspectives that firms may take are also found in the scientific literature and seem to have an effect on the research definitions of the term spirituality. Much of the Anglo-Saxon literature on workplace spirituality stresses the capability perspective much more than the diversity and discrimination perspective and focuses on non-religious spirituality at least as much as on religious 
spirituality (Daniel, 2010; Joelle \& Coelho, 2019; Karakas, 2010; Allen \& Paddock, 2017). German papers and statements focus more on legal aspects, on diversity and discrimination topics, and - closely linked to these aspects - on religious spirituality because it is only religion that is a matter of law and of discrimination suits, not nonreligious spirituality (Alewell \& Rastetter, 2019; Antidiskriminierungsstelle des Bundes, 2016; Gyo, 2016). Thus, the country context may influence perspectives on and definitions of spirituality at work, too. These differing foci may be due to the specific laws in the countries or cultural spheres, or to different cultural traditions regarding spirituality. Then again, they underline our assumption that we do need country-specific or culture-specific analyses of workplace

spirituality and that we need to analyse the whole spectrum of spirituality including religious and non-religious spirituality in order to get comparable results and analyses for specific countries.

We will now turn to the situation in Germany and will take stock of what we know about (the whole spectrum from religious to non-religious) spirituality at work in German enterprises.

\section{Spirituality in the Workplace in German Firms: What Do We Know Empirically?}

After we have examined what to look for concerning workplace spirituality in German firms, we now turn to our research question: What do we know about the perceptions of employers or firms on spirituality at work in Germany? We will first present and justify our methodological approach and will then present our results.

\section{Approach and Method}

The topic of spirituality at work has seen little scientific attention in Germany. To date, to our best knowledge, there is only more or less anecdotal empirical information on spirituality at work in Germany. Concerning the use of spiritually minted tools by companies in the private sector in Germany, we found only a few empirical references regarding which tools are used, and what perceptions on efficient use, on effects and consequences for the organisation there are. Only one text cites many examples from diverse companies - a brochure of the German Governmental Institution against Discrimination (Antidiskriminierungsstelle des Bundes, 2016), besides a number of reports in newspapers. We found no single quantitative or largescale study on employer strategies in German firms or employee attitudes and perceptions concerning spirituality at work in Germany.

As a first step to augment the empirical knowledge on tools related to spirituality at work used in Germany, we systematically screened the online versions of six major nationwide German newspapers (Süddeutsche, Der Spiegel, Fokus, Frankfurter Allgemeine, Die Welt, TAZ) and some regional newspapers (Westdeutsche Allgemeine Zeitung, Hamburger Abendblatt, Tageszeitung München, Augsburger Allgemeine, 
Berliner Zeitung) dated between 2007 and 2017. We searched for the keywords spirituality (Spiritualität), yoga (Yoga), prayer room (Gebetsraum), room of silence (Raum der Stille), meditation (Meditation) and burnout prevention (Burnoutprävention), always in combination with 'at work' (am Arbeitsplatz). We did not follow any hypotheses on the temporal development of the use of tools and practices within this time span but aimed at covering a ten-year span to get a broad picture of spirituality at work in Germany. We focused on gaining initial insights into HRM practices, conflict and discussion issues in organisations, and - in preparation for a qualitative study - on how to ask for spirituality at work in the business context.

Figure 1. Research Framework

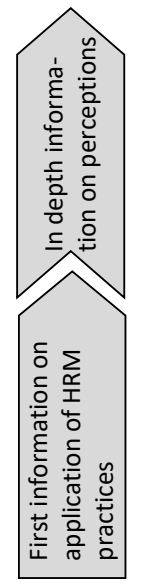

Type of information

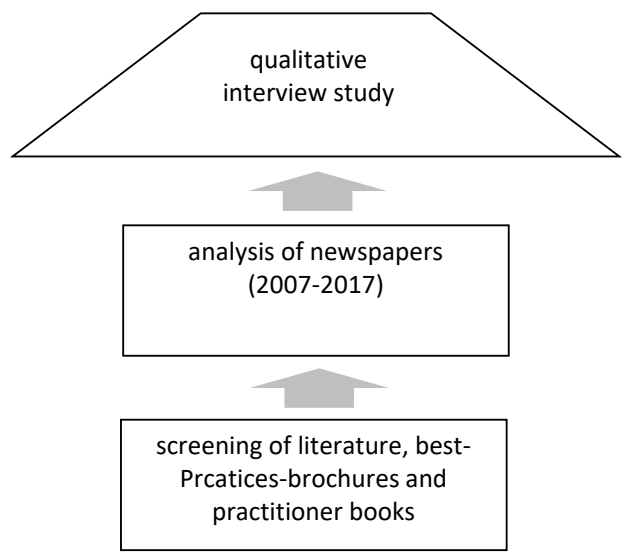

Source of information

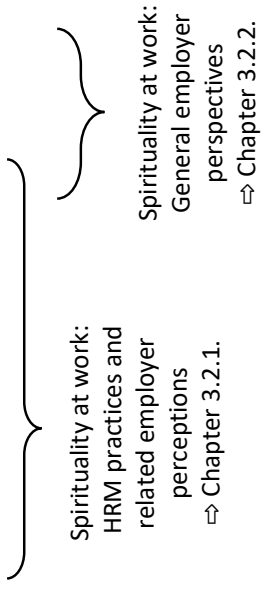

Aspects of analysis

In step 2, we conducted 10 qualitative interviews with experts such as managing directors, board members, HR managers and production managers from companies in Northern Germany so as to gain detailed information on their perceptions of workplace spirituality in organisations in general as well as of specific HRM tools. We conducted the interviews during summer 2017. To ensure the readiness of business people to talk about the (as we assumed: sensitive) topic of spirituality in the business context, we acquired nine of 10 interviewees via the "Dialog Kirche und Wirtschaft" (Dialogue Between Church and Business), a communication panel between the Protestant church of Northern Germany, and its participants from firms with (Protestant) faith-based and business backgrounds. Owing to the interviewees' membership in the communication panel, we dealt with a special sample population with considerable closeness to and a positive view of (Christian, protestant) spiritual issues. With regard to sectors, the sample consists of representatives from banking, legal advice, consulting, auditing, retailers, service organisations, suppliers 
and disposal companies. We also interviewed representatives of two ecclesiastical institutions as representatives of faith-based organisations. Our research framework is depicted in Figure 1.

\section{Results and Discussion}

In this section on results, we first present HRM practices used in German companies and related perceptions and expectations from the employer's side. We summarise the scarce findings from literature and (best) practice brochures in a first step and enrich them with the results of our newspaper analysis and the findings from our qualitative study in a second and third step. Afterwards, we look at employers' overarching and more general perceptions towards spirituality at work.

\section{HRM Practices and Related Expectations and Perceptions on the Employer's Side}

Only a few sources provide more or less anecdotal information on HRM practices, attitudes and perceptions related to spirituality at work. Nonetheless, summarizing this material and complementing it with newspaper research and interview information can provide first insights into the spectrum of spiritually minted HRM practices and employer perceptions in Germany.

The Diversity Perspective

Literature. Best practice publications often describe examples of HR activities of organisations concerning the diversity perspective (Antidiskriminierungsstelle des Bundes, 2016; Bertelsmann-Stiftung, 2008):

1. An interreligious calendar: To increase awareness of religious pluralism, some companies use an interreligious calendar on their intranet.

2. Some organisations use information brochures to actively sensitise and inform employees and customers about the main world religions and the adequate consideration of related specific employee needs at work.

3. Congratulation and seasonal greetings cards: Besides traditional Christmas cards, some organisations send congratulation cards, for example at the end of the Ramadan for Muslim employees.

Voigt (2013) perceived that, under comprehensive diversity perspectives and for compliance with the law, companies include religious issues (such as prayer rooms, religious clothing and food regulations) in diversity management because they need to guarantee prayer breaks and tolerate religious clothing if there are no important organisational reasons against this (Gyo, 2016).

Newspapers. Newspaper analysis did not produce any additional information on this point.

Interviews. Having Christmas celebrations and sending Christmas cards are the most common activities with a link to religion in our interviewees' organisations. 
While one company sends religion-neutral seasonal greeting cards, most interviewees who mentioned sending cards used Christmas cards. This somehow contradicts official positions of strict neutrality concerning religion (see below), yet interviewees explicitly defended it, arguing that Christmas forms part of German culture. Similarly, many of the interviewees' organisations have some sort of Christmas party - despite their official position of neutrality and despite diversity issues. We received no information on religion-neutral end-of-season parties, which would be a completely neutral and diversity-compliant alternative. However, these Christmas celebrations itself seldom have any reference to religion. They seem to be secular organisational parties, but some interviewees reported on successful parties with the collective singing of old (religious) Christmas songs and a fairly spiritual atmosphere. These explicitly Christian religious festivities show faint traces of a faithbased approach with its focus on one dominant religion, but we have no information on the interpretation of these festivities as religious or secular by employees and employers.

Although there is some public debate about the wearing of religious clothing or symbols, this topic seems to be of minor importance in the interviewees' companies. Their overwhelming opinion was that employers must generally permit such clothing or the wearing of such symbols owing to employees' legal rights. An interviewee representing an industrial company stated that wearing headscarves and cross necklaces is tolerated in his company. An interviewee from a consultancy stated that, in consultancy, employees wear hardly any and should not wear any religious symbols, since these may irritate clients. A lawyer made a similar statement concerning headscarves although this position was characterised as a personal opinion distinct from any official organisational position. Some interviewees said they were glad that there had been no major conflicts about this topic in their companies and that they have not yet had to take such decisions.

Summary. In sum, in light of the scarce evidence, companies under the diversity perspective seem to use a limited number of instruments and policies related to festivities and to religious symbols and clothing. Under the diversity perspective, companies apparently operate in a tension between a neutral position that only implements legally prescribed minimum standards to prevent discrimination, and aspects that go beyond neutrality and strengthen diversity (discourses) in the company. Following their different perceptions, companies take different positions within the theoretical framework of Miller and Ewest (2015): The neutrality position could be classified as faith-avoiding, but the handling of these aspects in the context of legally regulated diversity aspects points to faith-safe organisations.

The Needs Perspective

Literature. There are reports (Antidiskriminierungsstelle des Bundes, 2016; Bertelsmann-Stiftung, 2008) on specific HRM policies used by a few firms to address the needs dimension of spirituality at work, for example: 
1. Holiday planning: Since most of the official holidays in Germany are Christian festivity days, in some companies, employees with other religious needs may request holidays for non-Christian festivities.

2. Offering meals that conform to religious norms in canteens and at festivities, e.g. by extending opening hours during Ramadan, providing snack machines for fasting periods, or offering a comprehensive Iftar dinner.

3. Allowing prayer breaks and offering prayer locations upon employee request.

4. Installing intercultural agents - employees trained to initiate open discussions about cultural and religious needs and problems - as a first point of contact if employees or supervisors have problems or requests concerning culture and religion in groups and departments.

5. Installing intercultural and interreligious networks as a concept aiming at active discussions of topics around religious plurality and religious needs.

6. Granting permission to use sanitation facilities for ritual washing.

The authors of the Antidiskiminierungsstelle des Bundes (2016) argue that companies perceive effects as

- higher motivation and productivity because if employees can communicate their religious needs at work, the integration of employees in corporate social life will improve resulting in better performance

- higher loyalty owing to a higher perceived appreciation of their spiritual needs

- reduced absenteeism by including religious festivities in shift planning

- better acquisition of qualified employees, a more positive image of the employer and higher job satisfaction because the organisation cares about employees' religious needs.

Newspaper analysis. An analysis of newspaper reports showed that, in some organisations, there are praying circles or meetings for collective prayer and lectures about holy scriptures. Die Welt (2010) reported that Deutsche Bank has a Christian prayer circle, which forms part of the bank's diversity management program, but we found no explicit public communication by the bank related to it. Westfälische Nachrichten (2014) reported on 23 prayer circles at Volkswagen; these use the firm's conference rooms or offices for their meetings during or before the workday. A perception of a more conscious and human climate was reported as one impact of these circles. The idea to establish these circles spilt over from Daimler, where similar communities were installed earlier. There is a network of people of Christian faith in the automobile industry that organises prayer circles and celebrates services together (Bayerischer Rundfunk, 2020).

We also found reports on two room types for practising spirituality at work: rooms of silence (for meditation, yoga, relaxation) and prayer rooms. Rooms of silence re- 
portedly exist(ed) at the finance office of Bavaria (TAZ, 2015a), at ThyssenKrupp's Essen factory (Westdeutsche Allgemeine Zeitung, 2016), at Ikea (BertelsmannStiftung 2008, p. 64; Antidiskriminierungsstelle des Bundes, 2016, pp. 16-17) and at the hospital of Pinneberg (Abendblatt, 2012). Prayer rooms were reported at BMW in Munich (Süddeutsche Zeitung, 2015) and in several hospitals, for instance, the Red Cross hospital in Einkehr (TAZ, 2015b), at the Catholic hospital Groß Sand in Hamburg (Hamburger Abendblatt, 2007), at the University Medical Center Hamburg-Eppendorf (UKE) (Hamburger Abendblatt, 2009), at the hospital Elmshorn (Hamburger Abendblatt, 2012), and at Helios-Marien-Klinikum Hochfeld (Westdeutsche Allgemeine Zeitung, 2015b). Fraport offers multiple prayer rooms for different religions (for employees and for the airport's passengers) and a Muslim Friday prayer that enjoys broad participation among Fraport's workforce and is held by a professional Hodja (Antidiskriminierungsstelle des Bundes, 2016). In the newspaper articles, we found no perceptions of religious tensions or conflicts around the use of rooms of silence or prayer rooms in private businesses; however, we found many reports on conflicts in universities.

Interviews. Our interviews provided the following related information: Employees practice devotion and prayer (such as in prayer circles) in both ecclesiastic organisations we surveyed. Only in one commercial organisation, a retailer, an informal prayer circle by employees meets in the employer's conference rooms but outside work shifts. However, most surveyed companies reported caring about employees' religious needs relating to prayer breaks or holiday planning (for religious festivities such as Ramadan) by providing flexible holiday permission. There are no specific organisational rules for prayer breaks but mutual agreements with the direct supervisor or with co-workers. According to the interviewees, employees generally have to use regular breaks for their prayers to ensure a normal operating schedule.

With the exception of one interviewee, who reported a Muslim prayer room in a blue-collar division of his organisation, interviewees from companies did not report the existence of designated prayer rooms or rooms of silence. However, both of the surveyed ecclesiastic organisations have a Christian prayer room.

Nonetheless, praying during the workday is possible in most of the surveyed businesses. Some of the companies offer co-working spaces where employees may pray or meditate. Prayer is sometimes possible in offices, co-working spaces with separated working niches or other confined spaces in the production area. The interviewees argued that the equal treatment paradigm hinders the provision of prayer rooms because, with many religious traditions, the company would have to provide multiple prayer rooms to ensure equal treatment of members of all religions (Moll, 2017, pp. 47-48).

The surveyed organisations follow the scheme of legal holidays in their working time regulations. Concessions to meet non-Christian religious festivities are made within the regular regulations about flexitime, home office work and teleworking. 
One interviewee stated that granting longer and flexible release of absence for private purposes should generally follow from the commandment of brotherly love and charity regardless of the specific purpose, and purposes such as childbirth or the nursing of relatives should be handled similarly as religious purposes, for example, a pilgrimage or fasting period.

Religion-conforming diets are an explicit topic in three interviews (Moll, 2017), for instance, that companies provide explicit information about the ingredients of food and/or provide an additional vegetarian meal every day as an attempt to ensure religion-conforming food offerings in their canteens. Interviewees also perceived conflicts around eating and drinking: In one company, Muslim workers asked to bring halal meat to an organisational barbecue and the employer to pay for it. The company approved the bringing of halal meat but denied the employees' request to pay for it although the employer paid for all the other food and drink at the barbecue. The interviewee stated the main reason was that the company did not want to undermine the equal treatment by accommodating the special needs of a small group of employees. He did not consent to the argument that equal treatment would have been to pay for religiously acceptable food of all employees. Another interviewee reported perceptions from her previous position in a company in the raw materials industry. During Ramadan, Muslim workers who worked at very high temperatures in blast furnaces needed to go to hospital owing to dehydration because they did not drink (enough) water during their shift to compensate for the high physical strain and heat. Even an explicit order from the occupational physician could not solve this problem, as their religious norms stood against such drinking during the daytime.

Summary. In sum, our evidence shows that German companies already apply a broad spectrum of practices and tools directed at the needs dimension. This may point to a (partially) faith-friendly stance on the part of employers - (as long as the Christian religion is addressed). However, issues of neutrality and equal treatment of different religions have to be discussed (see below). Organisations address the needs perspective via application of some room-related tools, working time-related tools, food-related offerings, and instruments that facilitate coordination and cooperation in multi-religious settings. The first three tool groups reflect the same structure - they react to needs stemming from religious norms and rituals and try to give employees (time-related, space-related, and food-related) opportunities to live out their religious needs at the workplace. The fourth group of coordination and communication tools addresses a more indirect need; it seeks to proactively lower or avoid perceived tensions or to ensure a perceived balance between religious or spiritual needs between employee groups.

The Capability Perspective

Literature. Turning to the capability perspective, Mingers and Wildburg (2015) have suggested a shift from shareholder value to the stakeholder approach and to corpo- 
rate responsibility concepts as a strategic approach to address employees' spiritual capabilities. Ghadiri et al. (2016) described how a recruiting agency in Berlin offers its employees daily facial expression meditation, which is supposed to nurture employees' spiritual capabilities. They describe perceived reactions as consistently positive ranging from positive interactions with colleagues to a better and quicker start to the workday, to lower anxiety in an individual's thinking. They report that the perceived working atmosphere has improved and that the supervisors got a better understanding of their employees' de facto stress levels (Ghadiri et al., 2016, p. 192).

Authors put forward that companies may perceive higher job satisfaction, better recovery and improved resilience owing to business yoga and autogenic training (Brandt, 2004). Authors also expect improved psychological health and burnout prevention, for instance, via meditation, yoga, breathing exercises, mindfulness, silence and compassion (Kairies \& Schrott, 2011; Daimler-Benz Foundation, 2015).

Newspapers. In the newspapers, we also found some additional examples of how organisations try to nurture employees' spiritual capabilities or foster health and wellbeing by applying the following tools:

1. Yoga, during or outside working hours (Süddeutsche Zeitung, 2012a, 2012b; Frankfurter Allgemeine Zeitung, 2012; Westdeutsche Allgemeine Zeitung, 2016).

2. Feng shui as a daily routine (Süddeutsche Zeitung, 2012a)

3. Meditation, during or outside working hours (Westdeutsche Allgemeine Zeitung, 2016)

4. Mindfulness training, seminars on leadership in balance, autogenic training and courses on stress relaxation (Der Spiegel, 2012).

Interviews. In our interviews, some interviewees interpreted (non-religious) spirituality as an individual capability, arguing that through coaching and mindfulness training, individuals become more aware of their inner spiritual life, which positively supports dealing appropriately with one's fellow employees or with oneself. The interviewees considered such support as especially important in situations of private crisis and exceptional individual circumstances, for instance, death of family members, job loss, or severe illness.

Yoga, Thai Chi, meditation and practising mindfulness are further instruments to integrate spirituality into the business world. In our interviews, yoga was the most dominant - nine of the 10 interviewees mentioned it. Obviously, firms can provide yoga with little effort. In most cases, there is cost splitting: employees invest time outside work, and the employer provides a space (a conference or sports room) and pays for a trainer. An interviewee from a disposal company perceived a high acceptance of yoga courses in her company. However, some interviewees said that there 
must be a critical mass of participating employees so as to reach the economically reasonable minimum participation level and that in businesses with a de-central structure, this may lead to the situation that such activities are offered only at headquarters but not at de-central locations. They thus feared unequal treatment of employee groups. A consultancy solved this problem by granting all their employees a specific amount of money for health issues that can be spent on yoga with an eligible provider or on any other health-related activities, whether inside or outside the company.

Only one of the organisations provides Thai Chi. Another interviewee can imagine providing this arguing that, through this activity, employees could find inner balance in the morning before work starts. Thus, he clearly perceives Thai Chi as a spiritual resource or capability.

Meditation was a topic of minor relevance in our interviews: Only one company provided meditation. Employees of another organisation practice meditative collective running. The interviewees had some reservations about employees meditating together with colleagues and differing interpretations regarding the social functions of breaks. Using the break room for meditation or other forms of spiritual recreation poses the risk of conflict with co-workers who feel that breaks are for socializing with colleagues or having a meal and conversations with colleagues but not for other forms of recreation and silence. One interviewee reported that persons who meditate are stigmatised negatively in his organisation (Moll, 2017, p. 48).

The interviewees mentioned different aspects of mindfulness as a resource: In their views, mindfulness strengthens attention to employees' personal needs, social competence when dealing with colleagues, and respect for employees. Mindfulness as a topic is integrated into executive training and coaching sessions for managers. To increase individual mindfulness, companies offered yoga, meditation, running, brief recreation during lunch breaks with a professional trainer or, in one case, a conference with a recreational aspect that included extended walks and a sauna visit.

Summary. In sum, we found that organisations from various sectors (e.g. education, communication, consumer goods, industry, insurance and finance) are offering some activities concerning spirituality, relaxation, yoga or mindfulness. In most cases, organisations perceive a related stress reduction, improving performance capabilities or prevention of health problems. These are the key motivators to foster employees' spiritual capabilities. Reasoning from the very limited evidence, companies seem to address spiritual capabilities - more or less exclusively - with relaxation and sport methods from the realm of non-religious spirituality. 


\section{Employer Perspectives and Stances: Differences Between Religious and} Nonreligious Spirituality

We found little information on the deeper structures - on employers' perspectives, perceptions and the stances on accommodating spirituality in the workplace - in the literature and the newspaper reports. However, during our qualitative interviews, we asked about the general perspective on and roles of spirituality in the workplace. Most interviewees described strong differences regarding religious and non-religious spirituality. For non-religious spirituality, they focused more on capability-related and health-related issues and see nonreligious spirituality generally as a less critical and sensitive issue than religious spirituality, which is associated with legal aspects, conflict, equal treatment and diversity.

Turning first to the perspectives and stances regarding religious spirituality, our interview results are as follows: For the two ecclesiastical organisations, religion is important and positive. Both organisations address religion proactively as an inner resource of employees and apply various tools. In contrast, we found a very different perspective in the business companies: The interviewees from these organisations considered religion and religiosity to be a "non-topic" in their companies and expressed these companies' explicit, specific and strict position of neutrality concerning religion in the workplace. The main reasons given for this policy were the attempt to ensure equal treatment of all employees, and privacy concerns. These interviewees saw religion as a private matter for employees that the organisation should not address. However, one interviewee remembered from his previous position at an executive magazine publisher that many organisations had prayer circles, religious conventions and various Protestant and Catholic rituals practised by employees (as in faith-friendly organisations). However, the publisher added that many of these spiritual activities have ceased (Moll, 2017, p. 52). On the surface, these statements characterise organisations that are - or have developed into - faithavoiding or faith-safe companies.

However, digging deeper, we found different aspects that indicate that religiosity does appear in organisations. Concerning most firms' official position of neutrality to spirituality and religion, some of these aspects are somewhat ambivalent and inconsistent:

Our interviewees generally had a predominantly positive view of religion and religious diversity, and on religion's role in living well together and for the well-being of society. Their organisations support the Protestant church and its communities in different ways. For instance, executives often engage in ecclesiastical committees. They hold honorary positions in a church synod or an advisory committee for the bishop, and the companies' employees initiate or support projects in their local church communities. The interviewees said that they do so not solely as a private person but as a member of their organisation and that their employers welcome and 
support such engagements. Thus, company members support religious organisations outside their own organisation but in their role as a company member.

However, within business organisations, religion is handled more implicit. Most interviewees report practising values-based leadership, and that their faith helps them to form their values and to make better decisions. For example, they mentioned benevolence, brotherly love, ecological sustainability, the conservation of creation and deep appreciation of other persons as values associated with both leadership and religion and consider these values as important. However, although these values are part of the Protestant tradition, to which our interviewees belong, they do not label them as religious or spiritual values, but as values that belong to a "cooperative society" (genossenschaftliche Werte) or the "honourable merchant" (ehrbarer Kaufmann) (Moll, 2017, p. 31).

Some interviewees argued for strict neutrality in firms concerning religion (Moll, 2017). They stated that employee religiosity must not be an instrument to ensure or increase organisational performance or success. They fear invading employees' privacy and exploiting their private religious resources for the company's sake. This statement is interesting because religiousness is usually seen as a capability (as in faith-friendly or faith-based organisations), and is interpreted on an individual basis as a resource for good decision-making and for improving leadership. Despite this, our interviewees felt that employers should not and must not utilise this capability and that companies should be completely neutral concerning individual spirituality and religiosity (as in faith-avoiding or faith-safe organisations).

In sum, while the perspectives regarding religious spirituality are a topic in our interviewees' organisations, the neutrality paradigm still appears to be very important to the business companies. In this paradigm, companies try to separate the spheres and ensure equal treatment and privacy of employees concerning religiosity. Nonetheless, we found topics - for instance, Christmas cards and company managers engaging with Christian organisations outside the firm - for which the business world and Christian religion/religiosity overlap, and where there is no clear separation of the spheres. Thus, neutrality may be perceived differently from the perspective of members of different religious confessions.

Furthermore, the interviewees defined religiosity as an individual resource or capability that may contribute positively to performance, or as something that must be considered for legal reasons. Thus, while we expect to find mostly faith-avoiding or faith-safe official company positions, we expect to find many intersections in and combinations of more positive positions, too.

Turning to the perspectives and stances regarding non-religious spirituality, we found very different results. In contrast to religiosity or religious spirituality, our interviewees viewed non-religious spirituality positively throughout. They interpreted nonreligious spirituality in organisations as relevant primarily at the individual level, 
and as adjacent to stress reduction, resilience, general recreation and sport. They also saw the individual spiritual search for meaning, purpose and community as important related aspects. One interviewee stated that (non-religious) spirituality has become better known in the business world during recent years, and other interviewees perceived spirituality and recreational practices as a growing societal trend. Some pointed out that recreational spiritual practices are more highly valued by the young generation. For most interviewees, there is a strong and positive link between (nonreligious) spirituality, performance and employee health and well-being. Therefore, a broad field of topics from opportunities for recreation, finding inner balance, methods to prevent burnout and medical-psychological issues are strongly associated with non-religious spirituality at work. Overall, the interviewees had a dominantly positive view of individual non-religious spirituality as a capability for a company and its employees.

In sum, our impression is as follows: Our interviewees view non-religious spirituality positively and perceived its popularity as rising in society, and companies use this capability of employees to reach the companies' goals and to enhance or retain the health and the performance of employees. Although the interviewees did not deny the danger of exploitation of employees' spiritual resources for organisational goals, they perceive the exploitation of non-religious spiritual resources as less likely and/or less problematic than the exploitation of religious resources. Thus, the perception of non-religious spirituality as a resource or capability in the entrepreneurial context is much stronger than the perception of religious spirituality (see Loo, 2017 with a related result for Canada).

\section{Conclusion and Future Research Avenues}

We gave a preliminary impression of the perceptions of spirituality at work in German private sector companies - on the very limited empirical basis.

Concerning nonreligious spirituality, our interviewees were very favourable, interpreting it as an individual resource and capability that improves employees' health, well being and performance. They had no content-related reservations against fostering this capability or accommodating underlying needs by having their company offer activities and courses, allocating space and time as well as paying for trainers and coaches but voiced a number of practical problems (regarding numbers of participants or equal treatment of different employee groups). Furthermore, there were many interpretations of non-religious spirituality to be adjacent and very close to companies' health management. However, there was one report of a negative stigma of meditation at the workplace.

Concerning religious spirituality, German business companies seem much more sceptical. They often take the official position of strict neutrality and of not mixing economic and HRM topics with religious ones. On the surface, most interviewees reported a strictly faith-avoiding position for their organisations. However, digging 
deeper into how aspects of religious spirituality and religion are practised, there are many intersections of strict neutrality. At the organisational level, there were a number of faith-safe reactions, especially under a diversity perspective, and reactions aimed at compliance with German law regarding religious freedom in the workplace. The interviewees fear that religious-based conflict will be hard to handle. At some points, the reactions were faith-friendly towards Christianity but faith-avoiding for non-Christian religions. This probably relates strongly to Islam, which is the largest religion besides Christianity, and the only one with an observable number of members in the German labour market and at German workplaces. Thus, research into religious workplace spirituality may have to differentiate between religions.

From our research on the newspapers, there is selective and incomplete evidence of a small number of companies that proactively apply a broad spectrum of activities, tools and models. More and better empirical evidence may reveal a faith-friendly position among (some of) these companies.

Our interviewees saw religious spirituality as an individual-level capability. They stated that their religious spirituality improves their decision-making, performance and well-being. Nonetheless, their overwhelming individual wishes are to keep religiosity away from the organisational level of policies or HRM activities and to leave it under the complete control of the individual. As complete individual control for all employees is only possible if the expression of religious identity in the firm is restricted and religion is basically lived only outside the firm, a truly faith-friendly position for religious spirituality at work is probably not acceptable to our interviewees even though they are persons of faith.

However, we are dealing with an empirical field that has seen very little academic attention in Germany. Our results are preliminary since they are not based on representative scientific research data but on an analysis of newspaper articles, anecdotal evidence from best practice brochures by state agencies and a small-scale qualitative study asking for perceptions of our interviewees. With regard to the insufficient academic research into the application of spirituality at work in private, non-ecclesiastical sectors in Germany, much research into almost all aspects of spirituality in Germany's private business sector is needed.

Researchers should differentiate between the individual and organisational levels, and as far as possible, between attitudes and expectations regarding spirituality of a more religious or more non-religious form even if both will not be completely separable. The research should seek to identify companies' driving forces for accommodating spirituality at work - the needs, diversity and capability perspectives on spirituality - and the basic approach a company adopts on the spectrum between the faith-friendly and the faith-avoiding positions, between more rejecting and more embracing positions (Miller \& Ewest, 2015). We do not yet know which factors influence this choice: Is it the employee structure, for instance concerning diversity characteristics? Do product, service and customer characteristics influence the ap- 
proach to spirituality at work? What roles do employee representations have in this decision? If firms choose an approach, how do they implement it, i.e. which tools and instruments do they apply? What are the effects on employees and on HRM outcomes? Furthermore, closely connected to the research into work systems, are employers' stances on spirituality at work valid for the whole company or for specific employee segments only (with differences, for example between the production section and management)?

Concerning employees and the needs perspective, it is interesting to ask about the scopes and levels of individual spiritual needs regarding working life. Do employees want to express their spiritual needs at work, or would they prefer to keep their spirituality private? How strong are spiritual needs for which employee groups (e.g. groups from younger and older generations), and are they growing or shrinking for the younger cohorts?

In light of discussions about religious differences between countries, regions and areas within countries, studies may collect data not only for different countries but also for different regions within a country. For instance, in Germany, we expect differences between the dominantly Protestant north, the dominantly Catholic south and the strongly secularised east.

\section{References}

Ahmed, A., Arshad, M. A., Mahmood, A., \& Akhtar, S. (2019). The influence of spiritual values on employee's helping behavior: the moderating role of Islamic work ethic. Journal of Management, Spirituality \& Religion, 16(3), 235-263. https://doi.org/10.1080/14766086.2019.1572 529

Alewell, D., \& Moll, T. (2021). Employers' strategies on faith at work. In E. Pio, R. Kilpatrick, \& T. Pratt (Eds.), Routledge studies in management, organizations and society. Reimagining faith and management: The impact of faith in the workplace (1st ed., pp. 117-130). Routledge. https://doi .org/10.4324/9781003041733-11

Alewell, D., \& Moll, T. (2018). Spiritualität am Arbeitsplatz: ein Thema auch für die Personalarbeit in Deutschland? In H. Surrey \& V. A. Tiberius (Eds.), Die Zukunft des Personalmanagements: Herausforderungen, Lösungsansätze und Gestaltungsoptionen (pp. 33-46). vdf.

Alewell, D., \& Moll, T. (2019). Religion, Religiosität und Spiritualität am Arbeitsplatz in deutschen Unternehmen. In D. Alewell \& W. Matiaske (Eds.), Standards guter Arbeit: Disziplinäre Positionen und interdisziplinäre Perspektiven (1st ed., pp. 107-138). Nomos. https://doi. org/10.5771/9783845299310-107

Alewell, D., \& Rastetter, D. (2020). On the (ir)relevance of religion for human resource management and diversity management: A German perspective. German Journal of Human Resource Management: Zeitschrift für Personalforschung, 34 (1), 9-31. https://doi.org/10.1177/23970022 19882399 
Allen, T. D., \& Paddock, E. L. (2017). How being mindful impacts individuals' work-family balance, conflict, and enrichment: A review of existing evidence, mechanisms and future directions. In J. Reb \& P. W.B. Atkins (Eds.), Cambridge companions to management. Mindfulness in Organisations: Foundations, research, and applications (pp. 213-238). Cambridge University Press.

Antidiskriminierungsstelle des Bundes (2016). Umgang mit religiöser Vielfalt am Arbeitsplatz. Retrieved 02.01.2017, from https://www.antidiskriminierungsstelle.de/SharedDocs/Downloads/ DE/publikatio-nen/Expertisen/Expertise_Umgang_mit_religioeser_Vielfalt_am_Arbeitsplatz_2 0160922.pdf?_blob=publicationFile \&v=3

Ashmos, D. P., \& Duchon, D. (2000). Spirituality at Work. Journal of Management Inquiry, 9 (2), 134-145. https://doi.org/10.1177/105649260092008

Bäckström, A. (2014). Religion in the Nordic Countries: Between Private and Public. Journal of Contemporary Religion, 29 (1), 61-74. https://doi.org/10.1080/13537903.2014.864804

Bayrischer Rundfunk. (2020). Ingolstadt: Christen beten für die Autobranche. Retrieved 10.02.2020, from https://www.br.de/nachrichten/kultur/ingolstadt-christen-beten-fuer-die-aut o-branche,RnAEEO5?UTM_Name=Web-Share\&UTM_Source=E-Mail\&UTM_Medium=L ink

Bell, E., \& Taylor, S. (2003). The Elevation of Work: Pastoral Power and the New Age Work Ethic. Organisation, 10(2), 329-349. https://doi.org/10.1177/1350508403010002009

Benefiel, M., Fry, L. W., \& Geigle, D. (2014). Spirituality and religion in the workplace: History, theory, and research. Psychology of Religion and Spirituality, 6(3), 175-187. https://doi.org/10.1 037/a0036597

Bertelsmann-Stiftung. (2008). Synergie durch Vielfalt: Praxisbeispiele zu Cultural Diversity in Unternehmen. Bertelsmann-Stiftung Gütersloh.

Brandt, S. (2004). Prävention und Gesundheitsförderung im betrieblichen Setting Eine Längsschnittstudie über die psychologischen Auswirkungen des Yoga und des Autogenen Trainings. http://w ww.viveka.de/studie/GesamteStudie_17_7_2.pdf

Case, P., \& Gosling, J. (2010). The spiritual Organisation: Critical reflections on the instrumentality of workplace spirituality. Journal of Management, Spirituality \& Religion, 7 (4), 257-282. https://doi.org/10.1080/14766086.2010.524727

Casey, C. (2002). Critical analysis of Organisations: Theory, practice, revitalization. Sage.

Daimler-Benz Foundation. (2015). Die gestresste Gesellschaft Burnout vs. Depression Volkskrankheit oder Modediagnose? Retrieved 03.03.2017, from https://www.daimler-benz-stiftung.de/cms/ima ges/dbs-bilder/publikationen/BK19_Burnout-vs-Depression.pdf

Daniel, J. L. (2010). The effect of workplace spirituality on team effectiveness. Journal of Management Development, 29 (5), 442-456. https://doi.org/10.1108/02621711011039213

Der Spiegel. (2012). Burnout: Maßnahmen der Dax-Konzerne. Retrieved 03.03.2017, from http:// www.spiegel.de/fotostrecke/burnout-massnahmen-der-dax-konzerne-fotostrecke-83540.html

Dickson, D., Hargie, O., \& Wilson, N. (2008). Communication, Relationships, and Religious Difference in the Northern Ireland Workplace: A Study of Private and Public Sector Organisations. Journal of Applied Communication Research, 36 (2), 128-160. https://doi.org/10.1080/00 909880801922847

Die Welt. (2010). Buddhistische Gelassenheit: Religiöse Vielfalt in den Unternehmen. Retrieved 03.03.2017, from https://www.welt.de/print/die_welt/finanzen/article11810758/Buddhistisch e-Gelassenheit-Religioese-Vielfalt-in-den-Unternehmen.html 
Duchon, D., \& Plowman, D. A. (2005). Nurturing the spirit at work: Impact on work unit performance. The Leadership Quarterly, 16 (5), 807-833. https://doi.org/10.1016/j.leaqua.2005.0 7.008

Duffy, R. D. (2006). Spirituality, Religion, and Career Development: Current Status and Future Directions. The Career Development Quarterly, 55 (1), 52-63. https://doi.org/10.1002/j.2161-0 045.2006.tb00004.x

Frankfurter Allgemeine Zeitung. (2012). Yoga für ein längeres Berufsleben. Retrieved 03.03.2017, from http://www.faz.net/aktuell/finanzen/meine-finanzen/die-freuden-des-alters/mitarbeitersp ort-yoga-fuer-ein-laengeres-berufsleben-11941143.html

Fry, L. W., \& Slocum, J. W. (2008). Maximizing the Triple Bottom Line through Spiritual Leadership. Organizational Dynamics, 37(1), 86-96. https://doi.org/10.1016/j.orgdyn.2007.11.004

Garg, N. (2017): Workplace spirituality and Employee Well-Being: An Empirical Exploration. Journal of Human Values, 23(2), 1-19. DOI: 10.1177/0971685816689741

Ghadiri, A., Ternès, A., \& Peters, T. (2016). Trends im Betrieblichen Gesundheitsmanagement. Springer Fachmedien Wiesbaden. https//doi.org/10.1007/978-3-658-07978-9

Giacalone, R. A. (2004). A Transcendent Business Education for the 21 st Century. Academy of Management Learning \& Education, 3 (4), 415-420. https://doi.org/10.5465/amle.2004.15112 547

Gupta, M., Kumar, V., \& Singh, M. (2014). Creating Satisfied Employees Through Workplace Spirituality: A Study of the Private Insurance Sector in Punjab (India). Journal of Business Ethics, 122(1), 79-88. https://doi.org/10.1007/s10551-013-1756-5

Gyo, C. (2016). Beschäftigung von Flüchtlingen. Springer Fachmedien Wiesbaden. https://doi.org/ 10.1007/978-3-658-18154-3

Habermas, J. (2006). Religion in the Public Sphere. European Journal of Philosophy, 14 (1), 1-25. https://doi.org/10.1111/j.1468-0378.2006.00241.x

Hamburger Abendblatt. (2007). Muslimischer Gebetsraum in Groß Sand. Retrieved 03.03.2017, from http://www.abendblatt.de/hamburg/harburg/article107306824/Muslimischer-Gebetsrau m-in-Gross-Sand.html

Hamburger Abendblatt. (2009). Raum der Stille eingeweiht. Retrieved 03.03.2017, from http://w ww.abendblatt.de/hamburg/article106785016/Raum-der-Stille-eingeweiht.html,

Hamburger Abendblatt. (2012). Die Elmshorner Krankenhaus-Moschee. Retrieved 03.03.2017, from http://www.abendblatt.de/region/pinneberg/article106557243/Die-Elmshorner-Kranken haus-Moschee.html

Heliot, Y., \& Gleibs, I.H., \& Coyle, A., \& Rousseau, D.M., \& Rojon, C. (2020): Religious identity in the workplace: A systematic review, research agenda, and practical implications. Human Resource Management, 59, 153-173. https://doi.org/10.1002/hrm.21983

Hollenbach, D. (1993). Contexts of the Political Role of Religion: Civil Society and Culture. San Diego Law Review, 30 (4), 877-901.

Joelle, M., \& Coelho, A. M. (2019). The impact of spirituality at work on workers' attitudes and individual performance. The International Journal of Human Resource Management, 30 (7), 1111-1135. https://doi.org/10.1080/09585192.2017.1314312 
Kairies, K., Schrott, E. (2011). Förderung psychosozialer Gesundheit in Unternehmen durch Entwicklung von Spiritualität - eine Betrachtung mit Blick auf ayurvedische Strategien. https://www. researchgate.net/publication/304747859_Forderung_psychosozialer_Gesundheit_in_Unterneh men_durch_Entwicklung_von_Spiritualitat_-_eine_Betrachtung_mit_Blick_auf_ayurvedische _Strategien

Karakas, F. (2010). Spirituality and Performance in Organisations: A Literature Review. Journal of Business Ethics, 94(1), 89-106. https://doi.org/10.1007/s10551-009-0251-5

Kim-Prieto, C. (2014). Religion and Spirituality across Cultures (Vol. 9). Springer Netherlands. https://doi.org/10.1007/978-95-017-8950-9

Konz, G. N.P., \& Ryan, F. X. (1999). Maintaining an Organizational spirituality: no easy task. Journal of Organizational Change Management, 12 (3), 200-210. https://doi.org/10.1108/0953 4819910273865

Krahnke, K., Giacalone, R. A., \& Jurkiewicz, C. L. (2003). Point-counterpoint: measuring workplace spirituality. Journal of Organizational Change Management, 16 (4), 396-405. https://doi.o rg/10.1108/09534810310484154

Krishnakumar, S., \& Neck, C. P. (2002). The "what", "why" and "how" of spirituality in the workplace. Journal of Managerial Psychology, 17 (3), 153-164. https://doi.org/10.1108/026839 40210423060

Lips-Wiersma, M., Lund Dean, K., \& Fornaciari, C. J. (2009). Theorizing the Dark Side of the Workplace Spirituality Movement. Journal of Management Inquiry, 18(4), 288-300. https://doi .org/10.1177/1056492609339017

Loo, M. K. L. (2017). Spirituality in the Workplace: Practices, Challenges, and Recommendations. Journal of Psychology and Theology, 45(3), 182-204. https://doi.org/10.1177/009164711 704500303

Marty, M. E. (1993). Religion: A Private Affair, in Public Affairs. Religion and American Culture: A Journal of Interpretation, 3 (2), 115-127. https://doi.org/10.1525/rac.1993.3.2.03a00010

Mensah, H. K., Asiamah, N., \& Azinga, S.A. (2019): The association between nurses' religiousness and job satisfaction: Does materialism account for a moderation effect?. International Journal of Ethics and Systems, 35(3), 426-443. https://doi.org/10.1108/IJOES-04-2018-0061

Mirvis, P. H. (1997). Crossroads - "Soul Work" in Organizations. Organization Science, 8 (2), 192-206. https://doi.org/10.1287/orsc.8.2.192

Mitroff, I. I., \& Denton, E. A. (1999). A Strange but Formidable Alliance: Barriers to Studying and Defining Spirituality. In I. I. Mitroff \& E. A. Denton (Eds.), Warren Bennis signature series. A spiritual audit of corporate America: A hard look at spirituality, religion, and values in the workplace. Jossey-Bass Publishers.

Miller, D. W., \& Ewest, T. (2013). The Present State of Workplace Spirituality: A Literature Review Considering Context, Theory, and Measurement/Assessment. Journal of Religious \& Theological Information, 12(1-2), 29-54. https://doi.org/10.1080/10477845.2013.800776

Miller, D.W. \& Ewest, T. (2015) A new framework for analyzing Organizational workplace religion and spirituality, Journal of Management, Spirituality \& Religion, 12:4, 305-328, https://doi .org/10.1080/14766086.2015.1054864

Mingers, S., \& Wildburg, P. (2015). Systemische Beratung und Spiritualität. In M. Mohe (Ed.), Innovative Beratungskonzepte: Ansätze, Fallbeispiele, Reflexionen (pp. 119-138). Springer Fachmedien Wiesbaden. https://doi.org/10.1007/978-3-658-07942-0_6 
Moll, T. (2017). Spiritualität, Religiosität und Religion am Arbeitsplatz: eine explorative empirische Untersuchung in deutschen Unternehmen [master thesis]. University of Hamburg, Hamburg.

Moll, T. (2020). German-language Scales for Spirituality at Work. Journal of Management, Spirituality \& Religion, 17(03), 270-291. https://doi.org/10.1080/14766086.2020.1765191

Pandey, J., \& Singh, M. (2019). Positive Religious Coping as a Mechanism for Enhancing Job Satisfaction and Reducing Work-family Conflict: A Moderated Mediation Analysis. Journal of Management, Spirituality \& Religion, 16(3), 314-338. https://doi.org/10.1080/14766086.2019 .1596829

Petchsawang, P., \& Duchon, D. (2009). Measuring workplace spirituality in an Asian context. Human Resource Development International, 12 (4), 459-468. https://doi.org/10.1080/136788 60903135912

Pew Research Center. (2002). Among Wealthy Nations... U.S. stands alone in its embrace of religion. Retrieved 11.01.2019, from http:/www.pewglobal.org/2002/12/19/among-wealthy-nations/

Pew Research Center. (2015). Americans are in the middle of the pack globally when it comes to importance of religion. Retrieved 11.01.2019, from http://www.pewresearch.org/fact-tank/2015/1 2/23/americans-are-in-the-middle-of-the-pack-globally-when-it-comes-to-importance-of-relig ion/

Silk, M. (2005). Religion and Region in American Public Life. Journal for the Scientific Study of Religion, 44 (3), 265-270.

Süddeutsche Zeitung. (2012a). Yoga für Finanzbeamte. Retrieved 03.03.2017, from http://www.s ueddeutsche.de/karriere/wellness-im-buero-yoga-fuer-finanzbeamte-1.198740

Süddeutsche Zeitung. (2012b). Business-Yoga im Büro. Retrieved 03.03.2017, from http://www.su eddeutsche.de/karriere/business-yoga-im-buero-baeume-umarmen-gegen-den-stress-1.1433574

Süddeutsche Zeitung. (2015). Zucker für die Kollegen. Retrieved 03.03.2017, from http://www.su eddeutsche.de/muenchen/was-in-unternehmen-geschieht-zucker-fuer-die-kollegen-1.2554024

TAZ (2015a). Söder sucht Rückzugsmöglichkeit. Retrieved 03.03.2017, from http://www.taz.de/!52 $60529 /$

TAZ. (2015b). Einfach nur für das Sein. Retrieved 03.03.2017, from http://www.taz.de/!5259 7371

Tourish, D., \& Pinnington, A. (2002). Transformational Leadership, Corporate Cultism and the Spirituality Paradigm: An Unholy Trinity in the Workplace? Human Relations, 55 (2), $147-$ 172. https://doi.org/10.1177/0018726702055002181

Tourish, D., \& Tourish, N. (2010). Spirituality at Work, and its Implications for Leadership and Followership: A Post-structuralist Perspective. Leadership, 6(2), 207-224. https://doi.org/10.11 $77 / 1742715010363210$

Voigt, V. (2013). Interkulturelles Mentoring made in Germany. Springer Fachmedien Wiesbaden. https://doi.org/10.1007/978-3-658-03205-0

Volkswagen Foundation (2016): Religious Pluralisation - A Challenge for Modern Societies. Retrieved 07.03.2017, from https://www.volkswagenstiftung.de/nc/veranstaltungen/veranstaltung sarchiv/detailansicht-veranstaltung/news/detail/artikel/religious-pluralisation-a-challenge-for-m odern-societies.html

Westdeutsche Allgemeine Zeitung. (2015b). Gebetsraum für Muslime. Retrieved 03.03.2017, from http://www.derwesten.de/staedte/duisburg/gebetsraum-fuer-muslime-aimp-id10685789.html 
Westdeutsche Allgemeine Zeitung. (2016). Aktive Mittagspause und mehr bei Thyssen-Krupp, RWE, Evonik. Aktive Mittagspause und mehr bei Thyssen-Krupp, RWE, Evonik. Retrieved 03.03.2017, from http://www.derwesten.de/staedte/essen/aktive-mittagspause-und-mehr-bei-t hyssen-krupp-rwe-evonik-id11844637.html

Westfälische Nachrichten. (2014). Im Einsatz für die Gebetskreise bei VW. Retrieved 03.03.2017,

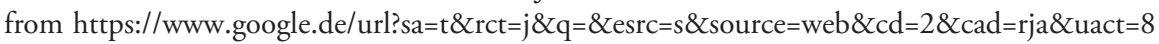
\&ved=0ahUKEwiiwP7028PQAhVCzRQKHY4QB-IQFggrMAE\&url=http\%3A\%2F\%2Fww w.kirchliche-diens-te.de $\% 2$ Fdms\%2Fhaus_kirchlicher_dienste $\% 2$ Farbeitsfelder\%2Farbeitswelt \%2FPresse\%2FArtikel-2014\%2FCAI-WN-03-02-2014\%2FCAI\%2520WN\%252003.02.201 4.pdf\%3F1439904537\&usg=AFQjCNEjfc63PjOowwELv47n-Fb5e7g05A\&sig2=73Di_S4sRz L80zScayjB6Q

Yang, F., Llu, J., Wang, Z., \& Zhang, Y. (2019): Feeling Energized: A Multilevel Model of Spiritual Leadership, Leader Integrity, Relational Energy, and Job Performance. Journal of Business Ethics, 158, 983-997. https://doi.org/10.1007/s10551-017-3713-1

Ziegler, J. (2013). Das Ideal einer neutralen Öffentlichkeit: Die Trennung zwischen Staat und Religion in Frankreich. Bundeszentrale für Politische Bildung, Dossier Frankreich. Retrieved 11.01.2019, from http://www.bpb.de/internationales/europa/frankreich/152521/laizitaet

Zinnbauer, B. J., \& Pargament, K. I. (2005). Religiousness and Spirituality. In R. F. Paloutzian (Ed.), Handbook of the psychology of religion and spirituality (pp. 21-42). Guilford Press. 